\title{
KS. PROF. JAN DECYK JAKO LITURGISTA
}

Każda śmierć w oczywisty sposób skłania do refleksji nad człowiekiem, którego życie zostało właśnie zakończone. Skłania także do próby podsumowania jego życiowego dorobku. W tego typu refleksjach muszą pojawiać się pewne oceny, które - gdy są pisane przez współpracownika bliskiego zmarłemu - z natury rzeczy nie do końca mogą być obiektywne ze względów zawodowych i emocjonalnych. Zastrzeżenia te wydają się wzrastać, kiedy śmierć przychodzi nagle, niespodziewanie, a tak stało się w przypadku śp. ks. prof. dra hab. Jana Decyka. Problem ten wydaje się jeszcze tym bardziej złożony, niemal symboliczny, kiedy uwzględni się, że jest to śmierć wybitnego liturgisty, którego głównym przedmiotem teologicznych rozważań był, odnowiony po Soborze Watykańskim II, kult zmarłych (sic!). Powyższy tytuł wyznacza zatem w jakiś sposób możliwości ukazania postaci śp. ks. prof. Jana Decyka i tym samym ogranicza znaczenie tego wymiaru, jaki zmarły pozostawił po sobie pośród tych, z którymi przyszło mu pracować, jako człowiek i kapłan. Niemniej, z całą pewnością dorobek naukowy cieszy się najtrwalszym walorem, a w głównej mierze ten, pozostawiony przez śp. ks. prof. Jana Decyka, pozostaje w orbicie liturgiki, stąd decyzja, by tak zatytułować niniejszy artykuł. Mimo tych zastrzeżeń trzeba także zauważyć, że w przypadku osoby ks. prof. Jana Decyka, wieloletniego pracownika ATK/UKSW, nie wypada choćby pobieżnie nie wspomnieć jego wkładu administracyjnego i - niech mi będzie wolno tak napisać - ludzkiego, gdyż nie pozostawały one bez wpływu 
na jego współpracowników, przyjaciół i studentów, z którymi dzielił i współtworzył środowisko nauki i pracy.

\section{$\dot{Z}$ YCIORYS}

Jan Władysław Decyk, syn Władysława i Stefanii z d. Sówka, urodził się 10 lipca 1945 r. w Morzyczynie Włościańskim, w parafii pod wezwaniem św. Jana Chrzciciela w Sadownem (obecnie diec. drohiczyńska). Po ukończeniu w 1963 r. Niższego Seminarium Duchownego Diecezji Płockiej - przebywał tam dwa ostatnie lata podjął studia filozoficzno-teologiczne w Wyższym Seminarium Duchownym tejże diecezji. 31 marca 1968 r. w Płocku przyjął sakrament kapłaństwa w stopniu diakona, a 15 czerwca 1969 r. w stopniu prezbitera w Wyszkowie. Pierwszą kapłańską posługę duszpasterską, jako wikariusz, podjął w 1969 r. w Wyszogrodzie. Jego następną placówką od 1972 r. była parafia pod wezwaniem św. Jana Chrzciciela w Płocku. W 1973 r. został mianowany spowiednikiem płockiego Niższego Seminarium Duchownego i pełnił jednocześnie funkcję diecezjalnego referenta Służby Liturgicznej. W 1974 r. został inspektorem Niższego Seminarium Duchownego w Płocku i funkcję tę pełnił przez siedem lat. Od 1981 r. podjął pracę w Biurze Misyjnym, działającym przy Konferencji Episkopatu Polski. Znaczna część życia ks. prof. J. Decyka przypadła poza diecezją macierzystą. W archidiecezji warszawskiej, gdzie mieszkał i pracował, na stałe był związany z kościołem ss. Wizytek. 23 marca 2016 r. został kanonikiem honorowym Kapituły Katedralnej w Płocku.

Ks. prof. dr hab. Jan Decyk zmarł nagle, gdyż po niespełna dobowym pobycie w Instytucie Gruźlicy i Chorób Płuc w Warszawie, w dniu 11 listopada $2016 \mathrm{r}$.

\section{PRACA NAUKOWO-DYDAKTYCZNA}

Jego rozwój naukowy znaczony był kolejnymi stopniami i tytułami. W 1974 r. uzyskał tytuł zawodowy magistra na podstawie pracy Abp Nowowiejski jako liturgista, napisanej pod kierunkiem 
ks. dra Stanisława Czerwika. Cztery lata później obronił doktorat u ks. prof. dra hab. Stanisława Grzybka, przedstawiając dysertację zatytułowaną Postuga pojednania w liturgii odnowionej po Soborze Watykańskim II. Po doktoracie pogłębiał swoje przygotowanie w Instytucie Teologicznym w Paryżu (1988-1989). Habilitował się w 1996 r. na podstawie rozprawy Rzeczywistość eschatyczna wedlug modlitw za zmarlych Mszału Rzymskiego Pawla VI: studium liturgiczno-teologiczne ${ }^{1}$. Tytuł naukowy profesora uzyskał w $2004 \mathrm{r}$. Od 1987 r. był związany zawodowo z ATK/UKSW, najpierw jako adiunkt, następnie profesor nadzwyczajny, i w końcu zwyczajny. W latach 1999-2005 sprawował urząd prodziekana Wydziału Teologicznego UKSW. Za pracę organizacyjną i naukową honorowany był nagrodami rektorskimi².

Ks. prof. Jan Decyk był kierownikiem Katedry Historii Liturgii Wydziału Teologicznego UKSW w latach 1996-2015. Pod jego kierunkiem powstało około 85 prac, w tym 10 doktorskich. Należy dodać, że spectrum badawcze pisanych prac znacznie wykraczało poza tytuł prowadzonej przez niego katedry3. Ważnym elementem

${ }^{1}$ Praca została opublikowana przez Wydawnictwo ATK w 1995 r.

${ }^{2}$ Honoraria zostały przeznaczone na potrzeby nowo powstających wówczas gmachów Uczelni.

${ }^{3} \mathrm{Z}$ prac doktorskich, o charakterze studium liturgiczno-historycznego, można wymienić: C. Bodzon, Życie liturgiczne diecezji płockiej w latach 1863-1939, Warszawa 2005, mps Biblioteka UKSW; B. Adamowicz, Formacja liturgiczno-pastoralna Akcji Katolickiej w diecezji płockiej w latach 1930-1939, Warszawa 2006, mps Biblioteka UKSW; W. Górski, Kult świętego Stanisława Kostki w diecezji płockiej w latach 1926-2007, Warszawa 2009, mps Biblioteka UKSW. Inne prace, mimo historycznych odniesień, posiadają charakter teologicznego studium liturgicznego lub liturgiczno-pastoralnego: J. Ziarko, Formacja eucharystyczna $w$ diecezji ptockiej $w$ latach 1946-2000, Warszawa 2003, mps Biblioteka UKSW; K. Filipowicz, Misterium Chrystusa w jutrzni i nieszporach adwentowej Liturgii Godzin, Warszawa 2005, mps Biblioteka UKSW; M. Stachlewski, Przygotowanie i obrzędy sakramentu matżeństwa $w$ polskich czasopismach teologicznych $w$ latach 1963-2003, Warszawa 2006, mps Biblioteka UKSW; D. Miśkowicz, Formacja liturgiczno-pastoralna Ludu Bożego w świetle Pierwszego Synodu Diecezji Rzeszowskiej, Warszawa 2006, mps Biblioteka UKSW; P. Waleńdzik, Miejsce liturgii 
pracy naukowo-dydaktycznej były comiesięczne seminaria otwarte, w których uczestniczyli w latach 2005-2015, oprócz doktorantów i studentów ks. prof. Jana Decyka, także zainteresowani liturgią. Tematyka seminariów dotyczyła historii liturgii, jak również bieżących zagadnień z życia Kościoła. Na zakończenie rocznego cyklu seminariów organizowana była przez Katedrę Historii Liturgii konferencja naukowa, niekiedy międzyuczelniana, z zapraszanymi w miarę możliwości prelegentami z zagranicy. W sumie odbyło się 10 takich konferencji ${ }^{4}$. Pierwsza konferencja była zatytułowana: „Liturgiczny dar czasu” (2006). W 2007 r. odbyła się konferencja pt. „Przestrzeń językowa w liturgii”, a następnie: „Liturgia rodząca piękno” (2008), „Liturgia trydencka dzisiaj” (2009), „Kapłaństwo wobec wspólnoty i kultury” (2010), „Różnorodność form celebracji eucharystycznych” (2011), „Wyznawcy Chrystusa wobec kultu świętych (2012), „Wiara

w nauczaniu pasterskim kardynała Stefana Wyszyńskiego, Warszawa 2010, mps Biblioteka UKSW; P. Cieślik, Prezbiter jako stuga $w$ świetle odnowionego po Soborze Watykańskim II Pontyfikatu Rzymskiego, Sandomierz 2011; R. Lisowski, Kształtowanie się kultu błogosławionego księdza Jerzego Popiełuszki, Warszawa 2013, mps Biblioteka UKSW; A. Sylwanowicz, Celebracja Eucharystii w nauczaniu Josepha Ratzingera/Benedykta XIV, Warszawa 2013, mps Biblioteka UKSW.

4 Pomysłodawcą seminariów otwartych, jak i tego, by ich roczny cykl wieńczyć konferencją naukową, był ks. prof. J. Decyk. W głównej mierze jemu przypadło określenie formatu tych spotkań. Niemniej, pozostawał zawsze bardzo otwarty na głosy seminarzystów i adiunkta. Samo prowadzenie seminariów zlecane było któremuś z seminarzystów-doktorantów, konferencje zaś prowadził któryś z zaproszonych prelegentów lub gości. Ks. prof. J. Decyk, jako kierownik katedry, rezerwował sobie przywitanie, wprowadzenie w tematykę konferencji i - co zajmowało mu stosunkowo dużo czasu - podziękowanie uczestnikom i organizatorom. Piszącemu te słowa, a więc adiunktowi, współorganizatorowi i niekiedy prelegentowi w jednej osobie, podziękowania te wydawały się nieproporcjonalnie długie i przesadne, toteż niejednokrotnie - zawsze bez skutku - zgłaszał takie uwagi. Dziś, z niewielkiej perspektywy czasu można powiedzieć, jak cenną inicjatywą były zarówno seminaria otwarte i konferencje, gdyż obok waloru naukowego wnosiły silny czynnik integrujący seminarzystów. Służyły temu też tzw. „spotkanie epifanijne”, które zgodnie z nazwą odbywały się w okolicy uroczystości Objawienia Pańskiego, zawsze w jakimś interesującym miejscu (sanktuaria, miejsca kultu, u znanych zgromadzeń zakonnych) i zawsze z odczytami prowadzonymi przez zaproszonych gości. 
i liturgia” (2013), ,Wkład świętych papieży w życie liturgiczne Kościoła” (2014), „Kult świętych w liturgii i życiu Kościoła” (2015).

\section{GLÓWNE TEMATY TEOLOGICZNE: ODNOWIONA LITURGIA W ORBICIE ODNOWIONEJ ESCHATOLOGII}

Ks. prof. J. Decyk jako liturgista koncentrował się przede wszystkim na kulcie zmarłych. Zagadnieniu temu poświęcił następujące monografie: wspomniana wcześniej Rzeczywistość eschatyczna według modlitw za zmartych Mszału Rzymskiego Pawła VI, Ludzki i Boży wymiar śmierci w świetle kultu zmarlych: studium liturgiczne, Eschata w Oficjum za zmarlych Liturgii Godzin ${ }^{5}$, Chrystus nadzieja wierzacych. Modlitwy za zmarlych w preces Nieszporów na każdy $d z i e n^{6}$. Tematyka ta obecna jest również w wielu jego artykułach ${ }^{7}$. Zakres podejmowanej problematyki pozwala widzieć ks. prof. J. Decyku jako najwybitniejszego znawcę teologii kultu zmarłych w Polsce, przy czym - co należy podkreślić - jest to teologia na wskroś posoborowa.

$\mathrm{Z}$ oczywistych względów badania nad kultem zmarłych pozostają w szerszym nurcie eschatologii, która od ponad stu lat zajmuje wśród dociekań teologicznych znaczącą pozycję. Joseph Ratzinger, jeszcze jako wykładowca na Uniwersytecie w Ratyzbonie w latach 70., pisał: „Sens eschatologii i jej wewnętrzna siła zależą od stopnia i zwrócenia się ku Chrystusowi, a nie od stopnia natężenia doczesnych oczekiwań na koniec świata czy tego świata przemianę. (...)

5 Publikacja ukazała się staraniem Wydawnictwa UKSW w 2003 r. Z pozycją tą wiąże się również uzyskanie tytułu profesorskiego.

${ }^{6}$ Publikacja ukazała się staraniem Wydawnictwa UKSW w $2008 \mathrm{r}$.

7 Z rozproszonych artykułów naukowych i popularnonaukowych można wskazać chociażby: J. D e c y k, Eschatologiczna myśl św. Pawła Apostoła inspiracja dla posoborowej liturgii pogrzebu, „Studia Płockie”, 37(2009), s. 45-56; Oficjum za zmarlych w Jutrzni i Nieszporach tworzywem homilii pogrzebowej, „Przegląd Homiletyczny”, 15(2011), s. 79-92; Obraz śmierci człowieka w posoborowej liturgii, „Communio", 32(2012) nr 3(179), s. 45-61; Oficjum za zmartych w Jutrzni i Nieszporach tworzywem homilii pogrzebowej, „Przegląd Homiletyczny”, 15(2011), s. 79-92. 
Elementem stałym i niezmiennym pozostaje chrystologia; od jej integralności zależy integralność reszty, a nie na odwrót". Uprawiana przez ks. prof. J. Decyka teologia kultu zmarłych zawiera ten właśnie wymiar, ale jest jednocześnie mocno wychylona ku człowiekowi, zgodnie z posoborowym modelem eklezjologicznym - człowiek droga Kościoła. Zapewne nie bez powodu w tytule jednej z wymienionych monografii jako pierwszy zostaje wymieniony ,ludzki”, a następnie „Boży” wymiar śmierci, chociaż nie o wartościowanie tutaj chodzi. Dlatego ks. J. Decyk pisze: „Jednocześnie [podkreślenie moje] teksty liturgii pogrzebowej wyrażają troskę o żyjących. Życie ludzkie bowiem, zarówno ziemska egzystencja, jak i wieczność, stanowią wielką integralną rzeczywistość życia dla Boga, od stworzenia po paruzję. Całe życie zmarłego jest darem przeznaczonym dla Boga. Antropologiczna interpretacja treści modlitw ukazuje człowieka jako byt osobowy, religijny, związany z osobowym Bogiem wiekuistym, który jest ostatecznym celem człowieka". Oczywiście, chodzi tutaj o antropologię biblijną, która ujmuje człowieka bardziej integralnie niż koncepcja dualistycza: dusza - ciało, przy jednoczesnym prymacie perspektywy życia wiecznego ${ }^{10}$.

Posoborowa wizja eschatologii, przenikająca liturgię za zmarłych, z upodobaniem przypominana jest we wnioskach wieńczących monograficzne dociekania: „Od czasu reformy liturgicznej Soboru Watykańskiego II eschatologia zyskała nową perspektywę - dokonał się w niej wieki przewrót. (...) Eschatologia rozszerzyła swą perspektywę o teraźniejszość. Pojęcie eschatologii nie może ograniczać się do kategorii bytu i porządku, ale powinno dotyczyć kategorii historycznego procesu, który zmierza ku przyszłości. (...) W tym nowym spojrzeniu na historię, nie należy więc patrzeć jak na jakąś próżnię, ponieważ celem historii tworzonej jest sam Bóg. (...) Nowe

\footnotetext{
8 J. R a t z i n ge r, Śmierć i życie wieczne, Warszawa 2000, s. 21.

9 J. D e c y k, Ludzki i Boży wymiar śmierci w świetle kultu zmarlych: studium liturgiczne, Warszawa 2000, s. 162.

10 Zob. Tenże, Eschatologiczna myśl św. Pawła Apostoła inspiracją dla posoborowej liturgii pogrzebu, art. cyt., s. 45-56.
} 
rozumienie eschatologii wymaga patrzenia na ludzkie życie w duchu Chrystusa, czyli przeżywanie go jako antycypacji przyszłości, która realizuje się w czasie z jego historycznymi uwarunkowaniami"'ll. Dodać też trzeba, że jako kierownik Katedry Historii Liturgii, chciał widzieć dawną eschatologię - w dużej mierze także i przedsoborowe rozumienie liturgii i liturgiki - w ujęciu już tylko historycznym: „Kończy się epoka - jak się wydaje - teologii inspirowanej dualizmem, ustępując miejsca teologicznej wizji zmartwychwstania w Jezusie Chrystusie. Dualistyczne rozumienie śmierci, jako rozłączenia duszy i ciała, pociągałoby za sobą rozumienie zmartwychwstania jedynie jako „dodatku” i uzupełnienia nieśmiertelności duszy. Więcej, owo złączenie ma się dokonać w kategorii temporalnej historycznego doświadczenia" "12. Tym samym, choć z właściwą sobie intelektualną ostrożnością, opowiadał się za teologiczną hipotezą zmartwychwstania w chwili śmierci. Będąc natomiast wiernym wspomnianym wyżej ideom antropologicznym i eklezjalnym, istotę paruzji uzupełniał o temat inauguracji Kościoła uwielbionego w Bożym Królestwie Wiecznym i tak też był postrzegany przez innych teologów ${ }^{13}$.

W eschatologicznym nurcie rozważań ks. prof. J. Decyka bardzo mocno wybrzmiewa najbardziej chyba tajemnicza i może z tego powodu nie zawsze doceniana przez teologów cnota nadziei. Liturgiczna modlitwa Kościoła za zmarłych stanowi naturalne siedlisko życiowe nadziei. Dzieje się tak głównie dlatego, a może pomimo dlatego, że chociaż śmierć człowieka, pozostając zawsze tajemnicą, nie powinna skłaniać wiernych do biernego oczekiwania przyszłości eschatycznej przez wycofanie się ze świata. Chrześcijańska nadzieja eschatologiczna jest przecież codzienną praktyką życia chrześcijańskiego, które jest de passage na ziemi. Analogia do rytów przejścia chrześcijańskiego pogrzebu, jaką czyni Ksiądz Profesor, jest oczywista. Modlitwę Kościoła za zmarłych nazywa wprost modlitwą nadziei

11 Tenże, Eschata w Oficjum za zmartych Liturgii Godzin, Warszawa 2003, s. 311-313.

12 Tamże, s. 313.

13 Por. Cz. B a r t n i k, Dogmatyka katolicka, t. 2, Lublin 2003, s. 867. 
wierzących ${ }^{14}$. Przy tej okazji proponuje odczytać na nowo znane liturgiczne adagium: Lex orandi - lex credendi, uzupełniane coraz częściej o lex vivendi. Propozycją Księdza Profesora w świetle powyższego stwierdzenia odnośnie do roli nadziei w życiu liturgicznym jest: Lex orandi-lex sperandi ${ }^{15}$. Raz jeszcze przy tej okazji dochodzi wyraźnie do głosu antropologiczny zwrot w teologii, w tym także w eschatologii. Ks. prof. J. Decyk pisze wręcz: „Zyskuje ona [eschatologia] miano chrześcijańskiej dopiero wówczas, gdy w perspektywie swoich zainteresowań uwzględni wewnętrzną relację człowieka z Jezusem Chrystusem. (...) Dzięki takiemu spojrzeniu na teologię, eschatologia jawi się jako teologia nadziei. Chrześcijanin staje się człowiekiem nadziei, którą jest dla niego Chrystus (por. Kol 1, 27)"16.

Chociaż myśl eschatologiczna wydaje się dominować w badaniach naukowych ks. prof. J. Decyka, to nie można zapominać, że pozostawał on zawsze liturgistą. Za punkt wyjścia swoich dociekań brał zazwyczaj teksty odnowionych modlitw liturgicznych, stąd Misterium Paschalne, ze szczególnym akcentem na fakt zmartwychwstania, jest stałym punktem odniesienia: „Zmartwychwstanie Chrystusa wraz z Jego śmiercią stanowi jedność jako Paschalne Misterium Chrystusa. (...) Zmartwychwstanie Chrystusa dla całego świata oznacza punkt zwrotny, początek czegoś ostatecznego, nowy i trwały wymiar. Otwierają się wszystkie możliwości bytu człowieka i bytu stworzenia, czyli nowe życie (por. Rz 6, 4n), które staje się dostępne dla wszystkich i jako rzeczywistość, i jako możliwość. (...) Zmartwychwstanie oznacza przede wszystkim to, że Bóg z miłości do człowieka chce wszystko co cenne zachować, niczemu nie da zginać, nawet wszystkim ludzkim łzom i radościom" "17. Choć słowa te pochodzą z analiz liturgicznych tekstów modlitw za zmarłych, to trzeba przyznać, że

${ }_{14}$ Zob. J. D e c y k, Chrystus nadzieja wierzacych. Modlitwy za zmartych w preces Nieszporów na każdy dzień, Warszawa 2008, s. 189-193.

15 Zob. Tenże, Eschata w Oficjum za zmarlych Liturgii Godzin, dz. cyt., s. 315.

16 Tamże, s. 312.

17 J. D e c y k, Ludzki i Boży wymiar śmierci, dz. cyt., s. 130-132. 
idea Misterium Paschalnego, tak charakterystyczna dla odnowionej liturgii, obecna jest $\mathrm{i}$ w innych pismach Księdza Profesora ${ }^{18}$.

W orbicie zainteresowań, co przekładało się także na pracę dydaktyczno-naukową ks. prof. Jana Decyka, stałe miejsce zajmowała liturgia uświęcania czasu. Tematyka roku liturgicznego, świętowania niedzieli, zgromadzenia liturgicznego i liturgii godzin była przez szereg lat podejmowana przez niego podczas wykładów kursorycznych. Znalazło to również swoje odzwierciedlenie w publikacjach naukowych $^{19}$. Charakterystycznym rysem podejmowanej problematyki było ogniskowanie jej, zgodnie z postulatami soborowymi, wokół Misterium Paschalnego Chrystusa.

Charakterystyczny wątek liturgii „nowej” widać szczególnie na przykładzie problematyki poświęconej sakramentom. W tytułach publikacji pojawia się charakterystyczne dla Księdza Profesora określenie „,na nowo odczytany” ${ }^{20}$. Nie chodzi tutaj bynajmniej

${ }_{18}$ Zob. Tenże, Misterium Paschalne wpisane $w$ egzystencje człowieka, w: S. S z c z e p a n i e c, J. S u p e r s o n, J. M i e c z k ow s k i (red.), Introibo ad altare Dei, Kraków 2008, s. 143-156; Pascha jako szczyt roku liturgicznego, „Warszawskie Studia Teologiczne", 24(2011) nr 1, s. 107-120.

19 Zob. J. D e c y k, Niedziela dniem Pana i Chrystusa, w: Niedziela. VI tydzień społeczny. 6-9. V, Warszawa 1999, s. 41-63; Misterium Chrystusa w roku liturgicznym źródtem przepowiadania, w: W. Przyczyna (red.), Liturgia i przepowiadanie, Kraków 2010, s. 127- 147; Liturgia Godzin hymnem na chwałe Boga, „Studia Theologica Varsaviensia”, 49(2011) nr 1, s. 23 - 34; Żydowskie źródła liturgii chrześcijańskiej, „Communio”, 31(2011) nr 3(175), s. 67-84; Od świętowania szabatu do celebracji niedzieli, w: H. S ł o t w i ń s k a, L. P i n t a 1, M. Wy r o s t k i e w i c z (red.), Omnia transeunt-Caritas manet. Księga Jubileuszowa dedykowana Księdzu Profesorowi Władysławowi Głowie w siedemdziesiata rocznice urodzin, Lublin 2012, s. 81-94; Celebrowanie wiary - od źródet soborowych do nowej ewangelizacji, w: B. M i g u t $\mathrm{i}$ in. (red.), Sakramenty w Misterium Kościoła. Księga Jubileuszowa dedykowana ks. Czesławowi Krakowiakowi z racji siedemdziesiąych urodzin, Lublin 2014, s. 101-115.

${ }^{20}$ Będą to głównie: J. D e c y k (red.), Chrzest na nowo odczytany, Warszawa 2001 i Tenże, Sakrament chorych na nowo odczytany, w: M. O l c z y k, W. R a d e c k i (red.), Memoriale Domini, Gniezno 2010, s. 81-92. Z pozostałych publikacji dotyczących problematyki sakramentalnej można wymienić: Eucharystia ,fons et culmen” życia Kościoła wedtug Benedykta XVI, „Studia Loviciensia”, (2008) nr 10, 
o radykalne zerwanie z dziedzictwem liturgicznym, zwłaszcza gdy uwzględni się, że ks. prof. J. Decyk jako kierownik Katedry Historii Liturgii niejako zawodowo zobligowany był organizować na tym polu badania teologiczne, jak i to, że większość jego wykładów zawierała wprost odniesienia do historii form ${ }^{21}$. Pozostając teologiem w pełni ukształtowanym przez odnowę liturgiczną, nigdy nie pomijał znaczenia dziedzictwa przeszłości. Stąd nawet jego największe monografie, w których zajmował się liturgią obecną, w dużej mierze zawierają odniesienia historyczne. Prawdą jest jednak, że dziwiła go odradzająca się w pojmowaniu liturgii tendencja, która przejawia wiele sympatii dla tradycjonalizmu, przy jednoczesnym niedocenianiu obligatoryjnego dziedzictwa reformy soborowej. Rubrycystyczne traktowanie liturgii budziło w nim poniekąd obawę. Nie umniejszało to w niczym szacunku Księdza Profesora dla odmiennych postaw i stanowisk.

\section{ZAMIAST ZAKOŃCZENIA - WSPOMNIENIE}

Dorobek naukowy ks. prof. Jana Decyka pozostanie prawdopodobnie najtrwalszym wkładem w dzieło recepcji odnowionej liturgii

s. 53-83; Liturgia godzin a Eucharystia, „Liturgia Sacra. Liturgia-Musica-Ars”, 14 (2008) nr 2/32, s. 329-341; Eucharystia paschalna droga Kościoła, „Słowo Krzyża”, 3(2009), s. 80-92; Sakrament pokuty i pojednania, w: W. Ś w i e r z a w s k i (red.), Mysterium Christi, Sakramenty i Sakramentalia, Zawichost - Kraków - Sandomierz 2013, 113-132.

${ }^{21}$ Do stałych wykładów kursorycznych o tematyce wybitnie historycznej należały m.in.: „Liturgia Godzin - geneza i dzieje”, „Liturgia w epokach kulturowych”, „Historia liturgii w Polsce”. Ze względu na więzi łączące Księdza Profesora z diecezją płocką, nie sposób nie wspomnieć o organizowanych przez niego badaniach mających na celu przybliżenie postać jednego z najwybitniejszych liturgistów swojej epoki, bł. Antoniego Juliana Nowowiejskiego. Znalazło to odzwierciedlenie w napisanych pod kierunkiem Księdza profesorach wielu pracach magisterskich i doktorskich. Wśród publikacji poświęconych Błogosławionemu można chociażby w kontekście problematyki sakramentalnej wymienić: J. D e c y k, Życie eucharystyczne pasterska troska błogosławionego arcybiskupa Antoniego Juliana Nowowiejskiego, „Studia Płockie", 36(2008), s. 97-111. 
w Polsce, myśli teologicznej i zaangażowania na rzecz UKSW. Pomimo tych niekwestionowanych osiągnięć, w pamięci współpracowników, studentów i przyjaciół środowiska, w którym przyszło mu pracować, najbardziej zostanie chyba zapamiętany nie tyle jako profesor i liturgista, ale jako ten, którego charakteryzował ujmujący szacunek wobec drugiego człowieka, niezależnie od zajmowanego stanowiska i pozycji w środowisku naukowym UKSW. Uwaga ta odnosi się w szczególny sposób do magistrantów i doktorantów, jak i szerszej rzeszy studentów. Chodzi tutaj nie tylko o dydaktykę czy intelektualny rozwój podopiecznych. Troska Księdza Profesora przybierała niejednokrotnie kształt materialnej, bezinteresownej pomocy. Należy także dodać do tego rzadko spotykany, ujmujący i skromny sposób bycia, przy jednoczesnym rozrzutnym gospodarowaniu czasem dla zainteresowanych ${ }^{22}$. Taka osobista postawa $\mathrm{w}$ połączeniu z wykonywaną pracą i funkcjami, jakie pełnił na ATK/UKSW, pozwalają widzieć w śp. ks. prof. Janie Decyku przykład powołania kapłańskiego i naukowego, zrealizowanego z oddaniem i pasją.

\section{Prof. F. Jan Decyk as a liturgist Summary}

This article is dedicated to Prof. F. Jan Decyk who suddenly past away. He was a priest of the Diocese of Plock. As a theologian of liturgy in his research and

${ }^{22}$ Na potwierdzenie powyższych słów pragnę przywołać wspomnienie poczynione przez Dziekana Wydziału Teologicznego UKSW, ks. prof. dr. hab. Piotra Tomasika. Zob. P. To m a s i k, Wprowadzenie, w: K. Filipowicz (red.), „Chlubimy się nadzieją chwały Bożej” (Rz 5, 2). Księga dedykowana ks. prof. dr. hab. Janowi Decykowi, Warszawa 2016, s. 10. W cytowanej publikacji zamieściło swe artykułu dwudziestu jeden teologów różnych specjalności. W większości podejmowane zagadnienia koncentrują się wokół cnoty nadziei i zostały pogrupowane w trzech działach: „Nadzieja w życiu moralnym i duchowym”, „Liturgia niosąca nadzieję”, „W orbicie katechezy i homilii”. Dobór tematu był nieprzypadkowy. Wszak cnota nadziei była szczególnie bliska Księdzu Profesorowi, co niejednokrotnie dał wyraz w swoich publikacjach. Ze względu na niespodziewaną i przedwczesną śmierć, nie udało się oficjalnie i uroczyście w ręczyć Księgi Jubilatowi podczas planowanego na tę okoliczność sympozjum. 
teaching activities he was bound with the environment of Cardinal Stefan Wyszynski University in Warsaw. From 1999 to 2005 Prof. F. Jan Decyk was the vice-dean of the Faculty of Theology of this University and in the years 1996-2015 he was the head of the Department of History of Liturgy. About 85 works including 10 dissertation were created under his direction. In his theological research he focused on the cult of the dead in renewed liturgy after Vatican Council II. These studies were the part of contemporary eschatology. The last part of the article, written by a student and professor's assistant, is kind of memory devoted to the friendliness that late prof. f. Jan Decyk showed to his students during his priestly and academic work.

\section{Prof. Jan Decyk als Liturgiker Zusammenfassung}

Dieser Artikel ist Prof. Priester Jan Decyk gewidmet, der plötzlich und unverhofft verstarb. Er war Priester der Diözese von Plock. Als Theologe der Liturgie war er mit seiner Forschung und Lehrtätigkeit der Kardinal Stefan Wyszynski Universität in Warschau verbunden. Von 1999-2005 war er Vize-Dekan der Theologischen Fakultät dieser Universität und in den Jahren 1996-2015 leitete er die Abteilung „Geschichte der Liturgie“. Etwa 85 Werke, einschließlich 10 Dissertationen entstanden unter seiner Leitung. Der Fokus seiner theologischen Forschung lag auf der Verehrung der Toten in der reformierten Liturgie nach dem Zweiten Vatikanischen Konzil. Diese Studien waren Teil der zeitgenössischen Eschatologie. Der letzte Teil dieses Artikels, geschrieben von einem Studenten und Assistenten des Professors, ist eine Art Gedenken, die der Freundlichkeit gewidmet ist, die der verstorbene Professor Priester Jan Decyk seinen Studenten während seiner priesterlichen und akademischen Wirkens entgegenbrachte.

\section{Professeur Père Jan Decyk comme liturgiste Résumé}

Cet article est dédié au professeur Jan Decyk qui est mort soudainement et de façon inattendue. Il était un prêtre du diocèse de Plock. En tant que théologien de la liturgie, avec ses activités de recherches et d'enseignement il a été relié à l'Université Cardinal Stefan Wyszynski à Varsovie. De 1999-2005, il était vice-doyen de la Faculté de Théologie de l'Université et dans les années 1996-2015, il dirigiait le département de 1'Histoire de la Liturgie. Environ 85 œuvres, dont 10 dissertations étaient créés sous sa direction. L'objectif de sa recherche théologique était sur le 
culte des morts dans la liturgie réformée du Concile Vatican II. Ces études faisaient partie de l'eschatologie contemporaine. La dernière partie de cet article, écrit par un étudiant et assistant du professeur, est une sorte de souvenir, qui est consacré à sa bonté que le regretté Professeur Père Jan Decyk apportait à ses étudiants au cours de ses activités sacerdotales et universitaires.

Słowa kluczowe: Jan Decyk, kult zmarłych, liturgia, eschatologia

Key words: Jan Decyk, cult of the dead, liturgy, eschatology

Schlüsselworte: Jan Decyk, Verehrung der Toten, Liturgie, Eschatologie

Mot-clés: Jan Decyk, culte des morts, liturgie, eschatologie

Nota o autorze: ks. Krzysztof Filipowicz, prezbiter diecezji warszawsko-praskiej, dr teologii w zakresie liturgiki, adiunkt Katedry Historii Liturgii Wydziału Teologicznego UKSW. W pracy badawczej zajmuje się rolą słowa, gatunków literackich i mistagogią w liturgii.

\section{Bibliografia:}

Bartnik Cz., Dogmatyka katolicka, t. 2, Lublin 2003.

Decyk J. (red.), Chrzest na nowo odczytany, Warszawa 2001.

Decyk J., Eschatologiczna myśl św. Pawła Apostoła inspiracja dla posoborowej liturgii pogrzebu, „Studia Płockie”, 37(2009), s. 45-56.

Decyk J., Od świętowania szabatu do celebracji niedzieli, w: H. Słotwińska, L. Pintal, M. Wyrostkiewicz (red.), Omnia transeunt-Caritas manet. Księga Jubileuszowa dedykowana Księdzu Profesorowi Władysławowi Głowie w siedemdziesiata rocznicę urodzin, Lublin 2012, s. 81-94.

Decyk J., Celebrowanie wiary-od źródeł soborowych do nowej ewangelizacji, w:

B. Migut i in. (red.), Sakramenty w Misterium Kościoła. Księga Jubileuszowa dedykowana ks. Czesławowi Krakowiakowi z racji siedemdziesiatych urodzin, Lublin 2014, s. 101-115.

Decyk J., Chrystus nadzieja wierzacych. Modlitwy za zmartych w preces Nieszporów na każdy dzień, Warszawa 2008.

Decyk J., Czas a wieczność w modlitwach za zmartych Mszału Pawła VI, Studia Theologica Varsaviensia", 33(1995) nr 2 s. 111-135.

Decyk J., Eschata w Oficjum za zmarlych Liturgii Godzin, Warszawa 2003.

Decyk J., Eucharystia „fons et culmen” życia Kościoła wedtug Benedykta XVI, „Studia Loviciensia”, (2008) nr 10, s. 53-83. 
Decyk J., Eucharystia paschalna drogą Kościoła, „Słowo Krzyża”, 3(2009), s. 80-92.

Decyk J., Liturgia godzin a Eucharystia , „Liturgia Sacra. Liturgia - Musica - Ars”, 14 (2008) nr 2/32, s. 329-341.

Decyk J., Liturgia Godzin hymnem na chwatę Boga, „Studia Theologica Varsaviensia", 49(2011) nr 1, s. 23 - 34.

Decyk J., Ludzki i Boży wymiar śmierci w świetle kultu zmarlych: studium liturgiczne, Warszawa 2000.

Decyk J., Misterium Chrystusa w roku liturgicznym źródtem przepowiadania, w:

W. Przyczyna (red.), Liturgia i przepowiadanie, Kraków 2010, s. 127-147.

Decyk J., Misterium Paschalne wpisane w egzystencję człowieka, w: S. Szczepaniec, J. Superson, J. Mieczkowski (red.), Introibo ad altare Dei, Kraków 2008, s. 143-156.

Decyk J., Niedziela dniem Pana i Chrystusa, w: Niedziela. VI tydzień społeczny. 6-9. V, Warszawa 1999, s. 41-63.

Decyk J., Obraz śmierci człowieka w posoborowej liturgii, „Communio”, 32(2012) nr 3(179), s. 45-61.

Decyk J., Oficjum za zmartych w Jutrzni i Nieszporach tworzywem homilii pogrzebowej, „Przegląd Homiletyczny”, 15(2011), s. 79-92.

Decyk J., Pascha jako szczyt roku liturgicznego, „Warszawskie Studia Teologiczne”, 24(2011) nr 1, s. 107-120.

Decyk J., Rzeczywistość eschatyczna wedtug modlitw za zmartych Mszału Rzymskiego Pawła VI: studium liturgiczno-teologiczne, Warszawa 2000.

Decyk J., Sakrament chorych na nowo odczytany, w: M. Olczyk, W Radecki (red.), Memoriale Domini, Gniezno 2010, s. 81-92.

Decyk J., Sakrament pokuty i pojednania, w: W. Świerzawski (red.), Mysterium Christi, Sakramenty i Sakramentalia, Zawichost - Kraków - Sandomierz 2013, 113-132.

Decyk J., Treści teologiczno-liturgiczne Mszy pogrzebowej $i$ w rocznicę śmierci w Okresie Wielkanocnym, „Studia Theologica Varsaviensia”, 30(1992) nr 2 s. 43-53.

Decyk J., Życie eucharystyczne pasterską troską błogosławionego arcybiskupa Antoniego Juliana Nowowiejskiego, „Studia Płockie”, 36(2008), s. 97-111.

Decyk J., Żydowskie źródta liturgii chrześcijańskiej, „Communio”, 31(2011) nr 3(175), s. $67-84$.

Filipowicz K. (red.), ,Chlubimy się nadzieją chwaty Bożej” (Rz 5, 2). Księga dedykowana ks. prof. dr. hab. Janowi Decykowi, Warszawa 2016.

Ratzinger J., Śmierć i życie wieczne, Warszawa 2000. 